\title{
Narrativas e tessituras adolescentes: metodologia e desafios de uma pesquisa(dora)
}

\author{
Narratives and adolescent tessituras: methodology and challenges \\ of a researcher
}

Rebeca Lloyd Gonçalves

Faculdade de Educação da Universidade Federal de Minas Gerais rebecalloyd@bol.com.br

Licinia Maria Corrêa

Professora associada da Faculdade de Educação da Universidade Federal de Minas Gerais - Brasil. Membro do Programa Observatório da Juventude liciniacorrea@gmail.com

Resumo: O presente artigo discute as possibilidades da entrevista narrativa como recurso teóricometodológico na pesquisa qualitativa em que a autora posiciona suas leituras acerca das representações construídas por adolescentes em cumprimento de medida socioeducativa. Relata-se o percurso investigativo e os exercícios contínuos que intencionaram traduzir com inteligibilidade o que as adolescentes pesquisadas trouxeram nas suas narrativas. A utilização das entrevistas narrativas orientou-se pela necessidade de compreender como as adolescentes (re)significavam o cumprimento da medida socioeducativa. Focalizando as experiências singulares de cada adolescente, observou-se que as narrativas provocam mudanças nas formas como os sujeitos compreendem a si próprios, aos outros e, por este motivo, são importantes estratégias causadoras de reflexão numa perspectiva emancipatória e de protagonismo juvenil. Conclui-se que essa metodologia possibilitou a aproximação entre a pesquisadora e as adolescentes, evidenciando a dimensão subjetiva no processo narrativo.

Palavras-chave: Entrevista narrativa. Pesquisa qualitativa. Adolescentes. Medidas socioeducativas.

Abstract: This article discusses the possibilities of narrative interview as a theoretical-methodological resource in qualitative research. The reflections raised come from the research that resulted in the master's thesis in which the author positions her readings about the representations constructed by adolescents in compliance with socio-educational measures. The investigative path and continuous exercises that intended to translate with intelligibility that the adolescents surveyed brought in their narratives are reported. The use of narrative interviews was guided by the need to understand how adolescents (re)meant compliance with the socio-educational measure. Focusing on the unique experiences of each adolescent, it was observed that narratives provoke changes in the ways in which the subjects understand themselves, others and, for this reason, are important strategies that cause reflection in a emancipatory perspective and youth protagonism. It was concluded that this methodology allowed the approximation between the researcher and adolescents, evidencing the subjective dimension in the narrative process.

Key-words: Narrative interview. Qualitative research. Teens. Educational measures. 


\section{Introdução}

Inúmeras pesquisas qualitativas são desenvolvidas na área da educação mostrando a teorização sobre esta metodologia, sendo importante citar as contribuições responsáveis pela difusão e pela construção do referencial teórico sobre o tema: Berger e Luckmann (2004), Haguette (2013), Ludke e André (2013), Fazenda (2010), Ferrer Ceveró (1995, upud Larrosa, 1995), Minayo (2016) e tantas outras.

Os estudos sobre as pesquisas qualitativas apontam que a escolha do(a) pesquisador(a) por uma temática não ocorre espontaneamente, visto que é resultado de interesses e circunstâncias socialmente experienciadas, sendo fruto de uma determinada inserção do(a) pesquisador(a) na sociedade, onde o olhar sobre os sujeitos está condicionado historicamente pela posição e lugar de fala que o(a) pesquisador(a) ocupa no mundo. Na realização desta pesquisa, alguns aspectos foram considerados, dentre eles: minha disponibilidade enquanto pesquisadora e a identificação com a temática estudada.

Inicialmente tínhamos a perspectiva de que as falas dos sujeitos constituíssem a mais fidedigna descrição dos fatos e que esta fidedignidade garantisse consistência à pesquisa. Logo percebemos que as apreensões que constituem as narrativas dos sujeitos são a sua representação da realidade e, como tal, estão repletos de significados e reinterpretações. Assentimos que, antes disto ser um problema, é a essência da pesquisa, pois, como explicitam Berger e Luckmann (2004, p.109), as análises têm "particular importância para a sociologia do conhecimento porque revelam as mediações existentes entre universos macroscópicos de significação, objetivados por uma sociedade, e os modos pelos quais estes universos são subjetivamente reais para os indivíduos”.

Esta investigação ancorou-se nas indagações que permearam os significados atribuídos por adolescentes do sexo feminino em cumprimento de medida socioeducativa de semiliberdade e nas possíveis (re)significações das narrativas dessas adolescentes, na busca de compreender suas percepções acerca do cumprimento da medida socioeducativa de semiliberdade.

Foi fundamental compreender a importância dada na relação dialética estabelecida entre narrativa e experiência, diante da necessidade de tempo para se construir a ideia de que, assim como a experiência produz o discurso, este também produz a experiência. Foucault (1999) refleti sobre os indivíduos em processo de constituição de si mesmos enquanto sujeitos de vivências e experiências, no curso desta pesquisa qualitativa confirmou o fato de que tanto o relato da realidade produz a história como ele mesmo produz a realidade. As adolescentes foram contando suas experiências, crenças e expectativas e, ao mesmo tempo, anunciaram novas possibilidades, 
intenções e anseios. Destarte, experiência e narrativa se conectaram tornando-se parte da expressão de vida dos sujeitos.

Em sua obra "As palavras e as coisas", Foucault (2016) nos remete à emergência das linguagens que buscarão produzir a verdade sobre o "homem" em diferentes campos de experiência, onde tais linguagens podem orientar a ação narrativa que conduzirá a (re)significação da realidade. Neste estudo, estabelecemos os parâmetros da pesquisa qualitativa que se adequaram melhor na nossa investigação e definimos que as narrativas seriam a principal fonte deste trabalho. No decorrer do processo, descobrimos que as narrativas não eram meras descrições da realidade, eram, especialmente, produtoras de conhecimentos e significados. As pessoas vivem histórias e, no contar dessas histórias, elas se reafirmam, modificam-se e criam novas histórias. As histórias vividas e contadas educam a nós mesmos e aos outros, incluindo os jovens e os recém-pesquisadores em suas comunidades (CLANDININ; CONNELLY, 2011, p. 27).

Relatamos, assim, a trajetória desta pesquisa qualitativa e dos exercícios contínuos que objetivaram traduzir com inteligibilidade o que as adolescentes pesquisadas trouxeram nas suas narrativas. Buscamos revelar, no decorrer do texto, os desafios da aproximação com as adolescentes, contornados por uma reflexão acerca dos discursos estigmatizantes a respeito desses sujeitos, a fim de se perceber como as políticas públicas lidam com o desafio de incluir os(as) adolescentes com um longo histórico de invisibilização social. Neste contexto, Salles (2007) nos aponta que os(as) adolescentes em situação de vulnerabilidades e de conflito com a lei estão submetidos(as) ao processo da "visibilidade perversa", que consiste na conversão generalizada do(a) adolescente numa criatura cruel, indigna e desumana.

\section{Compreendendo os sujeitos: metodologia da pesquisa narrativa}

Para quem escrevemos? Quem serão os sujeitos estudados? Quais contextos? Quais teorias? Quais resultados? Será que a pesquisa tem relevância ou faz sentido? Essas são reflexões pertinentes quanto tratamos da metodologia da pesquisa narrativa. Questões que devem ser consideradas demandas recorrentes à pesquisa narrativa como, por exemplo, o ir e vir durante o processo, que consiste no percurso da pesquisa, além da reflexão contínua, denominado por Clandinin e Connelly (2011) como estado de alerta.

Com a finalidade de utilizar no trabalho a metodologia da pesquisa narrativa, refletimos acerca dos termos citados por Clandinin e Connelly (2011), onde os aspectos pessoal e social são utilizados para tratar as interações de tempo, a fim de desenvolver noções de continuidade e 
lugares para marcar situações. Como o objeto de estudo da pesquisa narrativa são os sujeitos narrados, esses sujeitos precisam ser compreendidos enquanto aqueles que estão em interação num dado contexto social.

É importante entender a relação dialética entre teoria e realidade. Ao mesmo tempo que a realidade informa a teoria, esta, por sua vez, a antecede e permite percebê-la, reformulá-la, dar conta dela, num processo sem fim de distanciamento e aproximação (MINAYO, 2016, p.92). Este movimento precisa estar presente na prática investigativa que utiliza as narrativas como fonte de conhecimento. É importante não aprisioná-las, a priori, em categorias teóricas prédefinidas, porque este procedimento seria fortemente um cerceador do relato espontâneo.

Nesse sentido, a experiência é um fator importante para o desenvolvimento da pesquisa narrativa. Clandinin e Connelly (2011) entendem a experiência enquanto pessoal e social. A "Experiência acontece narrativamente e a pesquisa narrativa é uma forma de experiência narrativa" (CLANDININ; CONNELLY, 2011, p.49).

$\mathrm{Na}$ busca por compreender o que diziam as "minas" que se encontravam em situação de cumprimento de medida socioeducativa de semiliberdade, ficou evidenciado, por meio de suas narrativas, que elas falavam das violações sofridas envolvendo racismo, preconceitos sobrepostos em desigualdades sociais e de gênero, multiplicando os estigmas que permitiam "punir" as adolescentes por meio das "leis morais" institucionalizadas pelos usos e costumes $\square$ e pelo próprio Estado $\square$ que controlam os comportamentos de gênero.

\section{A entrevista narrativa no contexto das adolescentes em cumprimento de medida socioeducativa}

A pesquisa foi constituída na análise de conceitos baseados nos dados e informações obtidas através das entrevistas narrativas realizadas. O projeto e os objetivos de estudo foram apresentados à diretora e à pedagoga da Casa de Semiliberdade Belô, além de toda a documentação exigida pelo Comitê de Ética e Pesquisa da UFMG (COEP/UFMG), sendo que foram entrevistadas quatro adolescentes em situação de cumprimento de medida socioeducativa de semiliberdade.

Reafirmo que nessa pesquisa as entrevistas narrativas foram ferramentas indispensáveis para uma aproximação singularizada com as adolescentes. As entrevistas fizeram a entrevistadora chegar às informações elementares e acontecimentos únicos que "colocaram cada menina no lugar onde estavam", qual seja, na Casa 'Belô"', pois foi pelas entrevistas que emergiram histórias de vida, entrecruzadas no contexto situacional. 
Um dos instrumentos utilizados na pesquisa foi o gênero oral de entrevista narrativa, no qual pudemos observar a percepção que as adolescentes pesquisadas tinham da situação experienciada por elas naquele momento. O gênero entrevista narrativa é definido por Jovchelovitch e Bauer (2013, upud Bauer, 2013) como sendo uma entrevista com perguntas abertas e uma forma de encorajar os entrevistados. Questionamos os significados atribuídos pelas adolescentes do sexo feminino em cumprimento de medida socioeducativa de semiliberdade e as possíveis (re)significações das narrativas dessas adolescentes, na busca de compreender suas percepções acerca do cumprimento da medida socioeducativa de semiliberdade.

Outro aspecto importante desse tipo de entrevista é a possibilidade de interação face a face. Goffman (2004, p. 23) salienta a importância da interação face a face, para a reciprocidade, mostrando que "a interação face a face pode ser definida, em linhas gerais, como a influência recíproca dos indivíduos sobre as ações uns dos outros, quando em presença física imediata”.

As entrevistas narrativas deixam o sujeito livre para argumentar sobre o que julgam importante acerca de determinados temas, surgindo expressões instigantes como: "A manga já é azeda, aí você põe mais vinagre pra ficar mais azeda" (Rubi) ${ }^{2}$. Neste momento narrativo, a adolescente utilizou-se de uma metáfora para explicitar toda a pressão e opressão experienciados por ela na situação do cumprimento da medida socioeducativa. Nessa perspectiva, notamos que a oportunidade de fala foi uma maneira exitosa, na qual as adolescentes puderam transmitir situações vividas.

As entrevistas foram realizadas apenas pela pesquisadora principal deste estudo, à época, mestranda em Educação, a fim de manter o mínimo de influência possível nas respostas. Conforme Jovchelovitch e Bauer (2013, upud Bauer, 2013), o entrevistador não deve impor formas de linguagem não empregadas pelo sujeito durante a entrevista, mantendo a interação, como igual, consequentemente, aproximando-se dos sujeitos. As adolescentes, no momento da entrevista, dispuseram do tempo necessário para responder às perguntas, sem a interrupção da entrevistadora, ficando livres para expor suas histórias, ou o que julgassem necessário.

Para Lakatos e Marconi (2000), este tipo de entrevista visa encorajar e estimular o sujeito entrevistado a contar algo sobre algum acontecimento importante de sua vida e do contexto social. Jovchelovich e Bauer (2013) alertam para a importância de o entrevistador utilizar apenas a linguagem que o informante emprega, sem impor qualquer outra forma, já que o método pressupõe que a perspectiva do informante se revela melhor, ao usar uma linguagem espontânea. Essas asserções se assentam na compreensão de que a linguagem empregada constitui uma 
cosmovisão particular e, portanto, é reveladora do que se quer investigar: o "aqui” e o "agora" da situação em curso.

A nossa escolha pela escuta dos sujeitos não foi casuística. Na obra "Pensamento e Linguagem", Vygotsky (2011) propõe que se analise o aspecto intrínseco da palavra, pois é no significado da palavra que o pensamento e a fala se unem. O significado passa a ser ato de pensamento e linguagem que estão inter-relacionados, pois o pensamento refere-se à comunicação, à interação social, enquanto função primordial da fala, uma vez que é com o objetivo de se comunicar que o homem cria e utiliza os sistemas de linguagem e é a necessidade de se comunicar que impulsiona o seu desenvolvimento. Na ausência de um sistema de signos, linguísticos ou não, a comunicação torna-se limitada e torna o caráter mais afetivo, já que a transmissão racional e intencional de experiências e de pensamentos requer um sistema mediador - a fala. Ou seja, a verdadeira comunicação requer significado e generalização tanto quanto requer signos.

4 Narrativas sobre a vida das adolescentes fora da medida, da vida na medida e da vida sem medida

Apresentamos alguns fragmentos das narrativas das adolescentes pesquisadas e procuramos tecer, a partir do que elas trazem, suas (re)significações acerca da medida socioeducativa, suas percepções sobre os percursos de vida, seus sonhos, o olhar de cada uma sobre a Casa de Semiliberdade "Belô" e sobre o sistema socioeducativo. Compuseram essa tessitura as narrativas produzidas e os seus diálogos travados, apresentando as "minas" em suas preciosas singularidades, a partir da tangibilidade e percepção das suas vozes e histórias.

\subsection{Rubi}

Rubi estava com dezessete anos no período da pesquisa, natural de Governador Valadares, a uma distância de $323 \mathrm{~km}$ (trezentos e vinte e três quilômetros). Mencionou ser a mais nova de quatro irmãos e somente ela tinha um pai diferente, fruto do segundo relacionamento da sua mãe. Contou com tristeza sobre as falas reiteradas da mãe dizendo que, se tudo tinha dado errado para ela, era porque ela era a única filha de um pai diferente. A adolescente relatou que ouviu isto a vida inteira, sendo que a situação havia piorado, pois a mãe repetia a frase sempre que se lembrava de que ela estava "pagando medida"3.

A mãe de Rubi ainda teve um terceiro relacionamento, iniciado quando Rubi ainda era bem pequena. O padrasto a registrou e ela, inicialmente, tinha muita afeição por ele, tendo-o 
como o pai. Foi observado que a adolescente tinha no pulso uma tatuagem com as iniciais do nome da mãe e do padrasto e ela disse que tinha muita raiva dele e que a primeira coisa que faria quando saísse da casa de semiliberdade seria retirar a parte que fazia referência a ele na sua tatuagem. Também referiu-se com muita mágoa aos abusos sexuais sofridos na adolescência, sendo que, nesta parte da entrevista, Rubi ficou muito tempo calada e lágrimas silenciosas escorriam por sua face. Continuando sua história, falou sobre nunca ter tido coragem de contar para a mãe e nem para ninguém. Mas que foi a partir daí que começou a ficar uma adolescente muito revoltada, que desobedecia a mãe e só queria saber de ficar na rua. Foi então que, com a idade de doze para treze anos, conheceu um rapaz, dizendo que ele era muito ciumento. Foi questionado se ela parou de estudar nesta época, e Rubi respondeu que sim, por causa dos ciúmes do namorado e de umas "tretas" que arrumaram para cima dela na escola. À época do cumprimento da medida socioeducativa, a adolescente estava terminando, no período noturno, o último ano do ensino fundamental. Rubi disse que achava a escola "mega importante", pois só não estava no regime fechado, por causa das aulas de ciências.

(...) Óóóó o que o meu professor explicou: que uma faca, pra atingir o coração, tem que pegar por trás, porque aqui na frente, por causa dos ossos, não atinge, então, aí eu levei pra minha advogada, minha advogada fez minha defesa e, no julgamento, me ajudou e, por isso, eu peguei semi. E também porque foi em legítima defesa, porque ele tentou me matar, me agrediu e fez um monte de covardia, né, comigo... A escola me salvou sabe.

Quando Rubi se referiu à covardia, foi perguntado a ela sobre o quê especificamente estava falando.

(...) Me espancou, queria me matar asfixiada, eu tirei ele de cima de mim e peguei a faca e falei para ele não vir pra cima, a minha intenção era acertar o braço dele, porque, aí, ele parava, porque ele tinha amolado esta faca pra me matar. Aí, eu fui e acertei ele, só que, aí, eu levei ele na UPA55, socorri ele, só que, aí, depois de seis horas, ele não aguentou, porque, como ele fumava muito e as veias tava tudo entupida por causa do cigarro, e ele não aguentou e faleceu.

Quando foi questionado o que ela pensava depois de ter passado por tudo isto, Rubi respondeu: 
(...) Pra mim foi aprendizado, né, porque primeiramente isto tudo aconteceu, porque eu não escutei a minha mãe, infelizmente, porque, se eu tivesse escutado ela, eu não estaria aqui. Mas eu não vejo isto aqui como uma coisa ruim, sabe, é um aprendizado pra mim levar pra minha vida toda, porque eu, passado isto aqui, eu vou ter consciência do que eu vou fazer daqui pra frente, porque eu não quero voltar aqui mais, eu não vou ficar aprontando, pra voltar não só aqui, ou pra outros lugar pior, né, porque não é só aqui que é ruim, aliás, isto aqui não é vida, não. Então, eu tô com o pensamento de melhorar, ter as minhas coisas, ter dinheiro, comprar minha moto, ter minha casa e trabalhar.

Sobre sonhos, foi feita escuta sem demora e hesitação: "meu sonho é casar e ter uma casa. Mas o meu sonho mais louco mesmo é conhecer os jogadores do Cruzeiro". Posteriormente foi dialogado sobre o tempo em que ela passou na casa de semiliberdade, sobre o que ela achava da medida, sobre o futuro, de como ela percebia positivamente a escola como um lugar de possibilidades, ascensão social, mudança de vida, convivências e vivências da adolescência, mais livremente.

(...) Porque, aí, eu percebi o tempo que eu perdi, eu perdi dois anos de escola, perdi dois anos de aprendizado. Eu quero montar o meu salão. Então, minha amiga está fazendo psicologia, aí, eu vou estudar, não sei qual faculdade eu quero fazer, mas eu quero fazer faculdade. Passou rápido, né? Todo dia, então, eu acostumei com isto. Eu não aguento ficar aqui, acostumei sair todo dia, ir na escola de noite. Aí, nas férias, é muito difícil pagar, ficar aqui todo o dia, muito difícil pagar, mas está acabando, não vejo a hora.

Sobre uma pintura de travesseiro realizada durante a pesquisa, num processo de intervenção artística, Rubi relatou: “(...) Olha, aí, sabe a minha pintura, a do travesseiro, eu fiz como uma peça de teatro. Sabe que isso aqui é um grande teatro e a gente tem que colocar a máscara pra é dar conta de tudo".

\subsection{Esmeralda}

Penúltima filha de seis irmãs e um irmão, Esmeralda estava com treze anos quando participou da pesquisa. O pai e a mãe estavam presos. Ela e a irmã residiam em unidades de acolhimento institucional diferentes, até a época do acautelamento de Esmeralda. A adolescente relatou que os outros irmãos mais velhos estavam "seguindo a vida", sendo que um irmão e uma irmã residiam e trabalhavam em São Paulo. Sempre que falou dos pais, Esmeralda referiu-se recorrentemente à mãe, com muito carinho.

A adolescente é natural de Juiz de Fora, quarta cidade mais populosa de Minas Gerais e está a uma distância de $283 \mathrm{~km}$ (duzentos e oitenta e três quilômetros) de Belo Horizonte. Juiz de Fora possui uma unidade de internação e duas unidades de semiliberdade, sendo que nenhuma é 
feminina. Durante a entrevista, a adolescente continuou relatando sobre as ausências da mãe e do pai, suas idas e vindas entre unidades de acolhimento institucional e casas de parentes; emergiram em sua fala a dificuldade de manter uma vida dita "normal", nos "padrões", e sobre o começo de sua relação conflituosa com a escola e com tudo que interpõe rotinas e regras.

Vivenciando um contexto de trajetórias afetivas interrompidas, a adolescente narrou a história e o motivo pelo qual veio cumprir medida socioeducativa na Casa de Semiliberdade "Belô", sobre a relação com o uso de drogas e as interrupções do seu percurso escolar.

(...) Aí, eu briguei com a mulher lá no abrigo. Aí que deu esse desembolo todo. É que eu fumo maconha, aí, eu tinha chegado drogada, eu tomei meu banho, mas eu tinha usado muita droga, misturado balinha ${ }^{6}$ com maconha. Aí, eu fiquei muito ruim. Tava subindo o morro, assim, caindo aos pedaços. Aí, eu peguei, tentei sair e a mulher falou: Não, não vai sair não. Cê tá drogada, nós vai chama o diretor, o diretor tá vindo e vai conversar com ocê. Eu num quero conversa com ninguém, não. Quero ninguém pra conversar comigo, não. Aí, ela falou: -Esmeralda, fica de boa. De boa, nada. Aí, comecei a bater nela. Aí, ela subiu pro andar de cima e chamou a polícia.

Aí eu dormi, né? Porque a maconha dá um sono, dá uma fome. Aí, eu comi, deitei no sofá e apaguei. Aí, quando deu umas três horas, a polícia chego. Aí, as meninas gritando e eu tava, assim, meio tonta. Quê que foi? Quê que foi? Aí, falou assim: A polícia tá aí, Esmeralda. Cê tá presa de novo. Aí, me colocaram naquela bundinha do carro, lá. Que é naquela gaiola. Aí eu fiquei lá. Aí, eles me levaram pra delegacia. Aí, quando chegou na delegacia, conversei com o delegado. Aí, o delegado falou que eu tava muito nervosa e que eu ia ficar um dia no $\mathrm{HPS}^{7}$. Eu num vô fica lá, não, num vó fica lá, não. Aí, ele falou: Nós vamos colocar ocê é no lugar dos doidos, que é isso que você é.

As vivências fragmentadas por transitar em diferentes núcleos familiares e unidades de acolhimento institucional são relatadas pela adolescente. Assis e Constantino (2001) descreveram a inconstância do núcleo familiar com a metáfora "feito bolinhas de ping-pong", que pode ter implicações sérias no desenvolvimento infantil. Por consequência, os sentidos que a jovem dá a essas mudanças, são, sobretudo, de perdas, uma vez que ela relatou o sentimento de abandono de figuras simbólicas significativas. Não obstante, como dito anteriormente, se não houver um substituto afetivo, as adolescentes podem apresentar sentimentos de desamparo ou a crença de que ninguém se importa com elas.

$\mathrm{Na}$ Casa de Semiliberdade "Belô", Esmeralda apresentava muitos problemas nas relações com as outras adolescentes, com os(as) agentes e com os(as) trabalhadores da instituição. Era referenciada com frequência de forma antipatizada e conhecida pelo seu comportamento opositor, pelos seus rompantes e pela sua ansiedade. A adolescente participou ativamente de 
todas as atividades propostas, sendo que o comportamento opositor só ocorria quando ela era interpelada, ou provocada. Como as pessoas já sabiam de suas respostas a esses estímulos, as provocações aconteciam constantemente e, muitas vezes, as "comissões" que levou foram em decorrência disto.

É importante notar que, diferentemente do que, via de regra, acontece no sistema socioeducativo, Esmeralda já não aderia às normas, quando estava em unidades de acolhimento institucional. A adolescente colocava a medida socioeducativa como algo negativo, mesmo podendo ter acesso à escola, cursos e outras atividades com mais facilidade, na contramão do contexto social em que ela vivia.

A adolescente não ia à escola regularmente, enquanto estava morando em unidades de acolhimento institucional. $\mathrm{Na}$ Casa de Semiliberdade "Belô", também não frequentou a escola. À época, diziam que estavam encontrando dificuldades para matricular a adolescente, pelo fato dela ter chegado mais ao final do ano, especificamente em setembro. Quando questionada novamente sobre a escola, Esmeralda ratificou seu amor pelo handebol, falou sobre matar aulas e criticou outros processos da escola.

(...) No começo, eu gostava da escola, agora, num gosto mais, não. Estudá é o maió ruim. Eu não gosto, não. Quando entrei para a escola, só a professora e a minha irmã que me ajudava. Para casa, minha irmã colocava eu pra fazê. O que eu sabia, fazia, o que eu não sabia, eu chamava ela. Aí, ela me ajudava. Aí, eu odeio essas continhas do capeta, aquelas divisão, lá. Por isso que eu não gosto de escola. É o maior chato escola. Aí tem vez que a professora explica. Aí fala: Entendeu? Aí, todo mundo lá: Entendeu. E eu não entendi nada. Eu não quero fala que eu não entendi. É, ué.

(...) Vou falar aqui que só volto a estudar, se eu fazer handebol. Meu sonho é ser jogadora profissional de handebol. Antes, quando eu não usava droga, depois passei a fumar até às 10 horas, pra onda passar e eu jogar na escola à tarde. Tendeu?

Questionada sobre seus sonhos e perspectivas de futuro, a adolescente ressaltou: Se eu tivesse uma oportunidade de jogar num clube, eu ia tentar de tudo pra dar certo. Só o bandebol.

(...) Eu quero sair daqui e viver uma vida normal, como todo mundo vive. Agora, nesse instante, eu não vou mudar, não, mas, com o tempo, eu acho que eu mudava. A gente não muda de uma hora pra outra, né? Eu quero que minha mãe sai, pra mim morar com ela. Ela sai daqui a cinco anos e seis meses."Me dá um abraço?” (Abraço! Silêncio! Lágrimas!) 


\subsection{Diamante}

Diamante estava com dezoito anos quando participou da pesquisa. Nasceu e passou a infância no bairro Providência, situado na região norte da capital mineira. Segundo os dados da Secretaria de Gestão Compartilhada da Prefeitura de Belo Horizonte, esta é a regional que possui o menor IDH (Índice de Desenvolvimento Humano) da Capital Mineira. Posteriormente, Diamante foi morar no bairro Concórdia, situado na região nordeste da cidade.

É a segunda filha, de uma família de quatro irmãos, e não conheceu o pai biológico, sendo que foi o padrasto, já separado da mãe, que a registrou. Vivia no mesmo lote com a mãe, os irmãos e os avós. Neste momento da entrevista narrativa, Diamante expôs, com tristeza, a perda da avó e a prisão do irmão mais velho, na época com vinte anos, que cumpria pena em regime fechado na cidade de Bicas, região metropolitana de Belo Horizonte.

(...) Minha mãe me ajudava a fazer as tarefas. Minha mãe e minha vó. Meu vô morreu mais cedo que minha vó. Era uma família unida na mesma casa. Minha vó morreu, era tudo pra mim, quando ela morreu, eu quase morri também. Tenho três irmãos. Eu, o de seis e o mais velho, de vinte. Gosto muito dele. Ele tá preso em Bicas. Vou visitar ele, vou lá pegar o cadastro. Independente de tudo, eu amo ele. Na primeira visita da minha mãe, minha mãe falou que a primeira coisa que ele perguntou foi de mim: E a Diamante, mãe? -Tá presa! Diz que ele chorou demais. Falou: Falei pra ela ficar de boa, cuidar da filha. Ele fala da nossa filha, né! Nossa menina. Ele ama ela. Ela gosta dele demais. Tinha vez que ele ficava olhando ela. Fazia ela dormir. Ele pegou 32 anos. Tá fazendo uns artesanatos lá dentro.

Diamante engravidou aos quatorze anos, sendo que o pai não assumiu a filha. Durante a gravidez, conheceu outro rapaz com quem mantinha um relacionamento até a data da entrevista. Foi esse companheiro que lhe assistiu durante o parto, e sua filha o reconhecia como pai. A mãe de Diamante também engravidou, após ela ganhar sua bebê, e a adolescente contou que ela mantinha com a mãe uma relação ambígua, onde havia horas em que ela pensava que fosse a mãe e havia horas em que ela pensava que era a filha. Abaixo alguns relatos que ela fez a respeito da sua gravidez, seu parto e a relação com a mãe.

(...) Meu namorado. Vai fazer quatro anos que tamo junto. Minha filha chama ele de papai. Eu queria trabalhar, eu quero ter mais um. Quando minha filha nasceu, meu namorado assistiu. Ele e minha mãe ficaram fazendo umas caras estranhas, lá. Eu fiquei na banheira, mas não ganhei na banheira, não. Tiveram que romper minha bolsa. Ganhei anestesia, não. Nem ponto. Pôs um remédio lá, foi dilatando, pegou um canudo, estourou minha bolsa, aí, eu ganhei minha filha, 2h02, da madrugada. Minha mãe ganhou eu e meus irmãos tudo normal. 
(...) Ela apanha demais. Eles ficam batendo na menina. Eu não pus filho no mundo pra ser espancada. Eu já apanhei demais. Minha mãe me batia, porque eu fazia coisa errada. Me batia na adolescência. A minha filha é, é boazinha, mas ela é muito agitada. Minha mãe ficou sabendo que tava grávida com seis meses. Eu falei pra ela: “Sua barriga tá grande. Cê tá grávida”. Ela: “Grávida, não. Engordei”. "Então, tá". Fez exame. Seis meses. Primeiro falaram que era gastrite. Tava enjoando muito. Muita dor no estômago. Passaram um remédio, lá. Remédio preto, tipo conhaque. Nossa, minha mãe passava mal demais. Depois foi descobrir que era neném. Aí, o médico passou uns remédios pra ela, lá. Fez ultrassom e descobriu que era menino. Já tava dando pra ver. O único difícil que eu tô achando é que eu tô longe dela, né. Aí, eu vou, vejo ela no final de semana. Mas, pra criar, assim, não é difícil, não. Não é difícil, porque minha mãe me ajuda, porque, se eu fosse sozinha, tava lascada. Eu dou graças a Deus por ter a minha mãe. Eu e o pai dela não é junto mais, não. Mas, aí, eu tenho o meu namorado.

Quando Diamante falou sobre a escola, disse da enorme dificuldade que tinha para aprender os conteúdos escolares, além da impaciência em ter que ficar na sala de aula, pois não compreendia o que os professores explicavam. $\mathrm{Na}$ adolescência teve seu primeiro contato com o tráfico de drogas e foi assim que aprendeu, de cabeça, as contas de matemática. Segundo ela, precisava de dinheiro e não poderia errar. A relação com o saber e os sentidos da aprendizagem para a adolescente estavam intrinsecamente relacionados à sobrevivência.

(...) A escola é ruim. É que eu nem gostava de estuda, não. Num dava vontade de estuda, não. Porque antes eu só queria fica na rua, pra mim a rua era mais legal. Antes, eu ficava, eu ia pra escola e até matava aula. Eu ficava com meus colegas de resenha. Aí, minha mãe me batia, minha mãe me cobrava. A minha mãe me tirava da rua. Tinha vez que eu era expulsa da escola. Eu brigava na escola. Na escola tinha vez que eu ficava dentro, tinha vez que eu ficava fora. Nóis ficava dormindo lá fora, conversando. $\mathrm{Na}$ escola eu fico olhando, assim, vejo outras pessoas passando nas provas e eu tirano nota baixa, né? Aí, eu falava assim "Eu não sirvo pra estuda não, né?". Mas eu faço um esforço, né? Eu tenho dificuldade em matemática, mais ou menos, senão eu me ferro, porque não posso erra nas contas. Eu gosto dos professores, as coisas é que são difícil, mermo. Antes de vir pra cá, eu estava três anos sem estudá. Escola não é pra mim. Aí, eu fui presa de novo, por causa do tráfico de drogas. E agora eu fiz dezoito.

Podemos utilizar, nesse caso, o conceito de reconhecimento perverso (SALLES, 2007), a adolescente, na busca por emancipação, isto é, superação das dificuldades concretas de existência, de como suprir suas necessidades de subsistência, encontrou na infração uma possibilidade para se construir enquanto sujeito. Ao avaliar a "vida no crime", disse que ela era da vida "loka", que no crime o "papo é reto", você não pode errar e, se errar, tem que segurar o "bonde", cada um andando na sua linha. Com o dinheiro ganho com a venda de entorpecentes, Diamante narrou 
que comprava coisas que a filha necessitava, ajudava nas despesas de casa, comprava roupas para si e produtos de uso pessoal. Relatou que suas maiores diversões eram curtir baile e "dar umas pichadas" por aí.

Muito apaixonada pelo namorado, quando questionada sobre seus sonhos e desejos, Diamante sempre se referiu a ele, dizendo que estava pensando seriamente em sair "dessa vida loka", somente por ele. Pontuou que, depois de tanto tempo fora da escola, voltar a estudar, durante o cumprimento da medida socioeducativa, foi importante, pois a ajudaria a realizar seus objetivos.

\subsection{Safira}

Safira tinha quinze anos, quando participou desta pesquisa, e era a caçula de três irmãos. Morava num lote, com a família, na regional leste de Belo Horizonte, no Alto Vera Cruz. Segundo os últimos dados lançados pelo Índice de Vulnerabilidade Juvenil (IVJ/PBH), a região do Alto Vera Cruz é uma das regiões da cidade mais vulneráveis, com um alto índice de letalidade juvenil, sendo que um dos fatores importantes é a incidência pesada do tráfico de drogas. Aos quatro anos, Safira viu o pai e a mãe serem assassinados pelo tráfico. A avó, que morava no mesmo lote dos pais, passou a cuidar dela e dos irmãos. Safira pouco falava. Extremamente observadora, fazia tudo o que lhe pediam, com rapidez, e quase não se envolvia em nenhuma confusão. Realizou todos os cursos propostos pela Casa de Semiliberdade "Belô" e, à época da pesquisa, estava fazendo um curso de confeitaria. Durante as inserções da pesquisadora na Casa, sempre dava um jeito de se sentar ao lado desta última e, do nada, ia sussurrando o que queria dizer em meus ouvidos. Deixava os(as) agentes "loucos(as)", pois ninguém conseguia captar o que ela realmente estava dizendo. Quando percebia que Esmeralda novamente havia "caído numa jogada” e levado mais uma comissão, me dizia: “(...) É burra demais, já cansei de falar pra ela pra calar a boca, se fazê de besta, aqui tem hora e lugar pra falá as coisas. Tem que sabê como, quando é hora".

Muito perspicaz e inteligente, Safira não apresentava problemas na escola e cursava o oitavo ano do ensino fundamental. Porém, não escondia sua relação forte com o tráfico, um dos motivos pelo qual estava cumprindo a medida socioeducativa. $O$ outro motivo foi um acerto de contas onde houve uma tentativa de homicídio a outra adolescente, durante um baile funk. Safira era reincidente, já tendo passado várias vezes pelo sistema socioeducativo. Realmente, era uma adolescente de poucas palavras e um dia chegou atrasada para uma roda de conversa, pois tinha ido ao Centro Integrado de Atendimento ao Adolescente Autor de Atos Infracionais (CIA/BH), 
em decorrência de uma audiência. $\mathrm{Na}$ sua chegada, perguntou rapidamente o que estávamos fazendo e se poderia participar. Dado o aceite, sentou-se e começou a conversar, nos contando detalhes da audiência e sobre os garotos do Alto Vera Cruz que tinha encontrado lá.

(...) Ei, fessora! Vou querer participar. Advinha quem foi preso de novo? Quem? (Pronunciou o nome do adolescente). Tava chutando os carro, tá preso de novo. Naquela hora que eu cheguei lá, um bocado de meninos dentro do carro. Aí, a dotora de cabelo curtinho me atendeu, uma que usa óculos. O menino voltou tirando os cara. E você acha que os home num percebeu que os que tava lá tava é tirano os chefes? Os meninos do tráfico, do varejão. Tavam lá pagando o boi por causa do bagulho, tirano a chefia, de novo.

Quando questionada sobre seus sonhos, Safira disse, com tristeza, da morte da sua avó que estava com câncer. Falou das dificuldades enfrentadas por ela e os irmãos, em razão da ausência dela, e que, sobre sonhos, ela queria mesmo era sair dali, o mais rápido possível, e viver um dia de cada vez.

\section{Considerações Finais}

Diante da possibilidade de realizar uma análise das narrativas de histórias de vida das "minas na semi”, esta metodologia pode ter limitado a interpretação dos dados e, certamente, nosso olhar não abarcou toda a complexidade envolta nas situações de vulnerabilidades e conflito com a lei, acometidas pelas adolescentes. Destarte, acreditamos que trabalhar com narrativas foi um recurso importante para que as adolescentes pudessem explicitar seus processos de (re)significações.

Em que pese a singularidades das histórias de vida das adolescentes pesquisadas, notamos que o perfil das adolescentes desta pesquisa não destoa do perfil identificado em outras pesquisas que trataram da temática infração juvenil feminina (ASSIS, 2001; FACHINETTO, 2008). Das quatro adolescentes participantes, todas apresentaram defasagem escolar, com distorção idadesérie. Todas eram oriundas de classes pobres e apenas uma se autodeclarou branca. Apenas uma das adolescentes conhecia o pai biológico e a maioria provinha de lares cuja subsistência vinha das mulheres (mães/avós), sendo que para todas o cumprimento de medida socioeducativa foi a porta de entrada para acessar direitos fundamentais anteriormente violados, tais como escolarização, saúde, lazer.

As drogas se fizeram presentes na vida das adolescentes e o contato se deu em níveis diferenciados quanto ao uso e abuso. Reiteramos o caso de uma adolescente que estava cumprindo medida, pelo seu ato infracional ter início com o uso de drogas, uma vez que a 
situação de drogadição a levou a cometer ameaças e lesão corporal, em desfavor da trabalhadora da unidade de acolhimento institucional em que estava. Esta adolescente encontrava-se, desde a primeira infância, em uma espiral crescente de vulnerabilidade.

A ação proposta de escutar as adolescentes nos levou a repensar no totalitarismo que ronda nossas condutas e a refletir que, se o poder fosse potencializado produtivamente, no sentido de produzir comportamentos, atitudes, ideias e criação de canais de comunicação, o sistema socioeducativo teria a perspectiva de ser esculpido com a participação e o protagonismo dos(as) adolescentes, sendo permeado pelo cuidado de si, enquanto experiência de (re)significações.

As adolescentes apontaram, em suas narrativas, que a execução das medidas socioeducativas na Casa de Semiliberdade "Belô" se direcionava para a natureza punitiva e retributiva, com vieses de proteção temporária. Essa natureza nos remete ao reducionismo característico da doutrina de situação irregular, proposto pelo Código de Menores, a despeito das normativas nacionais e internacionais que tratam a execução da medida, potencializando seus aspectos sociais e pedagógicos, como diretrizes dos processos socioeducativos.

Reconhecer a existência de rastros da doutrina da situação irregular na ação socioeducativa é um enfrentamento que precisa ser feito. Mais do que isso, é algo que se coloca impositivamente quando há o reconhecimento das medidas socioeducativas como não meramente punitivas. Provavelmente seja essa a mais difícil das tarefas: superá-la e resolvê-la, um desafio que precisamos transpor para atendermos aos preceitos da doutrina da proteção integral.

Os processos envolvendo a sanção/comissão revelaram a atenção com a disciplina, negociadas com dispositivos que tinham pouco a ver com as propostas socioeducativas apontadas no SINASE (Sistema Nacional de Atendimento Socioeducativo). Esses jogos simbólicos estabelecidos discricionariamente para a promoção da disciplina, ordem e sensação de segurança, compelem às adolescentes demarcações hierarquizadas, relacionadas ao gênero.

Assim, sinalizamos a necessidade de produzir diálogos e pesquisas que atentem para a execução das medidas socioeducativas contemplando a categoria gênero em seus pressupostos teóricos e práticos, reconhecendo as adolescentes como sujeitos, apesar da sua reduzida representatividade na privação de liberdade. Elas existem e estão nos programas de atendimento socioeducativo indicando que a categoria gênero circunda o sistema socioeducativo.

Sem a intenção de abranger todo o contexto da medida de semiliberdade, é relevante e urgente qualificar esta medida como alternativa de potencialidade, essencialmente socioeducativa e comunitária, como um contraponto à internação. E, assim, canalizar os recursos da política 
pública para esta medida seria importante, visto a necessidade de implementar, no sistema socioeducativo de semiliberdade, Casas de Semiliberdade para o atendimento do público feminino nas comarcas do interior do Estado.

Diante da narrativa das adolescentes, a escola ocupa lugar fundamental na execução da medida socioeducativa, visto que todas as "minas" estavam com suas trajetórias escolares interrompidas e que a reinserção no contexto escolar possibilitou novas oportunidades de socialização com os pares, com a comunidade escolar e com as (re)significações acerca de suas histórias e seus sonhos. Apesar das narrativas carregarem histórias de dificuldades de aprendizagem e exclusão escolar, todas as adolescentes percebiam a escola enquanto um lugar de estabilidade, conhecimento, possibilidade de acessão social, acolhimento e socialização.

Por fim, acreditamos que a pesquisa qualitativa com entrevistas narrativa pôde provocar mudanças na forma como as adolescentes compreendiam a si próprias e aos outros, sendo possível fazer uma nova leitura de si. Foi um estudo da experiência como história, principalmente uma forma de pensar sobre a experiência, que pode ser desenvolvida apenas pelo contar histórias, e pelo vivenciar histórias. Nesse sentido, a narrativa foi o método de pesquisa e ao mesmo tempo o fenômeno pesquisado.

\footnotetext{
${ }^{1}$ Casa Belô: durante o percurso da pesquisa, esse foi o nome fictício que as adolescentes escolheram para denominar a Casa de Semiliberdade em que estavam.

${ }^{2} \mathrm{Na}$ investigação realizada, a qual aqui narramos, "as adolescentes pesquisadas escolheram num processo circular serem denominadas coletivamente como "minas" e individualmente pelo nome de uma pedra preciosa.

${ }^{3}$ Durante o campo da pesquisa, foi possível perceber que as adolescentes se referiam ao cumprimento da sanção como pagamento de comissão, seguindo a mesma lógica quando repetiam que estavam "pagando" medida socioeducativa. Todas as adolescentes referiam se ao cumprimento da medida sob a forma de "pagar a medida". Percebeu-se que estavam em situação de extrema vulnerabilidade social, devido à negativa de acessos aos serviços do Estado, tendo muitos de seus direitos constitucionais negados. No entanto, colocavam-se simbolicamente enquanto devedoras deste mesmo Estado que as invisibilizava e negava direitos a elas.

${ }^{4}$ A expressão "tretas" é uma gíria utilizada pela adolescente referindo-se a problemas.

${ }_{5}^{5}$ UPA: Unidade de Pronto Atendimento.

"Metanfetamina, popularmente conhecida como "balinha", é uma droga sintética estimulante cujos efeitos se manifestam no sistema nervoso central e periférico.

${ }^{7}$ HPS - Hospital de Pronto Socorro, onde são atendidas emergências médicas.

${ }^{8}$ Comissão: as adolescentes se referiam às sansões recebidas por alguma falta disciplinar ou ao regimento com a expressão "pagar comissão"
}

\section{Referências}

ASSIS, Simone G.; CONSTANTINO, Patrícia. Filhas do Mundo: infração juvenil no Rio de Janeiro. Rio de Janeiro: Fiocruz, 2001.

BERGER, Peter L.; LUCKMANN, Thomas. A construção social da realidade: tratado de sociologia do conhecimento. Rio de Janeiro: Editora Vozes, 2004. 
BRASIL. Lei n. 6.697, de 10 de outubro de 1979. Institui o Código de Menores. Disponível em: <http://www.planalto.gov.br/ccivil_03/leis/1970-1979/16697>. Acesso em: 20 jan. 2020.

BRASIL. Conselho Nacional dos Direitos da Criança e do Adolescente. Sistema Nacional de Atendimento Socioeducativo. Resolução n. 119, de 11 de dezembro de 2006. Dispõe sobre o Sistema Nacional de Atendimento Socioeducativo e dá outras providências. Disponível em: <http://www.mj.gov.br/sedh/ct/spdca/sinase/Sinase.pdf>. Acesso em: 20 jan. 2020.

CLANDININ, D. Jean; CONELLY, F. Michael. Pesquisa narrativa: experiências e história na pesquisa qualitativa. Tradução: Grupo de Pesquisa Narrativa e Educação de Professores ILEEL/UFU. Uberlândia: EDUFU, 2011.

FACHINETTO, Rochele Fellini. A "Casa de Bonecas"; um estudo de caso sobre a unidade de atendimento sócio-educativo feminino do RS. Dissertação (Mestrado em Sociologia) RS: Instituto de Filosofia e Ciências Humanas, Universidade Federal do Rio Grande do Sul, 2008.

FAZENDA, Ivani. (Org.). Novos enfoques da pesquisa educacional. São Paulo: Cortez. 2010. 135p.

FERRER CERVERÓ, Virgínia. La crítica como narrativa de las crisis de formación. In: LARROSA, Jorge. Déjame que te cuente. Barcelona: Editorial Laertes, 1995.

FOUCALT, Michel. Ditos e escritos II: Arqueologia das ciências e história dos sistemas de pensamento. Rio de Janeiro: Forense Universitária, 2000.

FOCAULT, Michel. A palavra e as coisas. Rio de janeiro: Martin Fontes, 2016.

GOFFMAN, E. Estigma: notas sobre a manipulação da identidade deteriorada. NUNES, Márcia Bandeira de Mello Leite (Trad.). Rio de Janeiro: LTC, 1971.

GOFFMAN, Erving. Manicômios, prisões e conventos. 6. ed. São Paulo: Perspectiva, 2004.

HAGUETTE, Teresa Maria Frota. Metodologias Qualitativas na Sociologia. Rio de Janeiro: Editora Vozes, 2013.

JOVCHELOVITCH, Sandra; BAUER, Martin W. Entrevista Narrativa. In: BAUER, Martin; GASKELL, George (Orgs.). Pesquisa qualitativa com texto, imagem e som: um manual prático. 11ed. Petrópolis: Vozes, 2013. p 90-113.

LAKATOS, Eva Maria; MARCONI, Marina de Andrade. Fundamentos de metodologia científica. 5. ed. São Paulo: Atlas, 2000.

LUDKE, Menga; ANDRÉ Marli E.D.A. Pesquisa em Educação - Abordagens Qualitativas. São Paulo: Editora Pedagógica e Universitária, 2013.

MINAYO, M.C. S. O desafio do conhecimento: pesquisa qualitativa em saúde. São Paulo: Hucitec, 2010.

MINAYO, Maria Cecília de Souza. (Org). Pesquisa Social: Teoria, Método e Criatividade. Rio 


\section{Dialogia}

GONÇALVES, Rebeca Lloyd; CORREA, Licinia Maria. Narrativas e tessituras adolescentes: metodologia e desafios

de Janeiro: Editora Vozes, 2016.

PREFEITURA MUNICIPAL DE BELO HORIZONTE. Índice de Qualidade de Vida Urbano de Belo Horizonte. Belo Horizonte: IQVU/BH, 2016. Disponível em: <http: portalpbh.pbh.gov.br>. Acesso em 15 fev. 2020.

Índice de Vulnerabilidade Juvenil de Belo Horizonte. Belo Horizonte: IVJ/BH, 2016. Disponível em: <http:gestaocompartilhada.pbh.gov.br>. Acesso em: 15 fev. 2020.

SALLES, Mione Apolinario. (In)visibilidade perversa: adolescentes infratores como metáfora da violência. São Paulo: Cortez, 2007. 360p.

VYGOTSKY, L. S. Pensamento e linguagem. São Paulo: Martins Fontes, 2011.

Recebido em: 28 fev. 2020 / Aprovado em: 15 abr. 2020

Cite como (ABNT 6023:2018)

GONÇALVES, Rebeca Lloyd; CORREA, Licinia Maria. Narrativas e tessituras adolescentes: metodologia e desafios de uma pesquisa(dora). Dialogia, São Paulo, n. 34, p. 167-184, jan./abr. 2020. Disponível em: https://doi.org/10.5585/Dialogia.N34.16706. 